\title{
The effects of nitric oxide on the immune system during Trypanosoma cruzi infection
}

\author{
Fredy RS Gutierrez, Tiago WP Mineo, Wander R Pavanelli, Paulo MM Guedes, João S Silva/+ \\ Departamento de Bioquímica e Imunologia, Faculdade de Medicina de Ribeirão Preto, Universidade de São Paulo, Av. Bandeirantes \\ 3900, 14049-900 Ribeirão Preto, SP, Brasil
}

\begin{abstract}
Trypanosoma cruzi infection triggers substantial production of nitric oxide (NO), which has been shown to have protective and toxic effects on the host's immune system. Sensing of trypomastigotes by phagocytes activates the inducible NO-synthase (NOS2) pathway, which produces NO and is largely responsible for macrophage-mediated killing of T. cruzi. $N O$ is also responsible for modulating virtually all steps of innate and adaptive immunity. However, NO can also cause oxidative stress, which is especially damaging to the host due to increased tissue damage. The cytokines IFN- $\gamma$ and TNF- $\alpha$, as well as chemokines, are strong inducers of NOS2 and are produced in large amounts during T. cruzi acute infection. Conversely, TGF- $\beta$ and IL-10 negatively regulate NO production. Here we discuss the recent evidence describing the mechanisms by which NO is able to exert its antimicrobial and immune regulatory effects, the mechanisms involved in the oxidative stress response during infection and the implications of NO for the development of therapeutic strategies against $\mathrm{T}$. cruzi.
\end{abstract}

Key words: Trypanosoma cruzi - nitric oxide - myocarditis - cytokines - regulatory T cells

Nitric oxide (NO) and the respiratory cycle: the beginnings of oxidative stress

Nitrogen monoxide, also called NO, is a low-molecular weight radical $(30 \mathrm{kDa})$ that performs multiple biologic activities. The biological importance of this ubiquitous intra- and intercellular signalling molecule was first described in the early 1980 s as being part of the endothelial derived relaxing factors (Furchgott \& $\mathrm{Za}$ wadzki 1980). NO was named "Molecule of the Year" in 1992 by the journal Science and, later that decade, studies were conducted to demonstrate its cardinal mechanism of action on vascular smooth muscle cells (Murad 1986). These studies made it clear that generation of NO by endothelial cells causes smooth muscle relaxation through activation of guanylate cyclase by nitrosation of its heme group. This work resulted in the Nobel Prize in Physiology and Medicine being conferred to Murad, Furchgott and Ignarro, in 1998 (Murad 1986).

It is hypothesised that NO may have originated in metazoans as an ancient mechanism of first-line defence against intracellular pathogens. This theory has been confirmed by the wide occurrence of the enzyme responsible for $\mathrm{NO}$ production, NO-synthase (NOS2), in several species, ranging from invertebrates (Ribeiro et

Financial support: FAPESP [2007/53940-0; FRSG (05/60762-5), TWPM (06/06803-4) and PMMG (07/04896-8)], The Millennium Institute for Vaccine Development and Technology (420067/2005-1), CNPq (JSS, WRP, PMMG)

+ Corresponding author: jsdsilva@fmrp.usp.br

Received 9 April 2009

Accepted 29 May 2009 al. 1993) to mammals and non-mammalian vertebrates. In mammals, $\mathrm{NO}$ production is upregulated in response to infection by a wide range of unicellular organisms such as bacteria, yeast and parasites (i.e., Trypanosoma cruzi) (Cardoni et al. 1990). Evidently, evolutionary diversity has induced NO synthesis to be performed in response to different kinds of stress stimuli.

Under homeostatic conditions, NO is produced at low concentrations from constitutive NOS2 and acts as an intracellular messenger and a cytoprotective (antioxidant) factor. Indeed, overexpression of NOS3 blocks the exocytosis of inflammatory mediators by endothelial cells, thus preventing blood vessel inflammation. Conversely, exposure to inflammatory stimuli leads to the production of substantial amounts of NO in a variety of cell types, as well as modifications of the cellular microenvironment, which by its turn upregulates NO effects. These effects are a consequence of the formation of dinitrogen trioxide and peroxynitrite at sites of simultaneous superoxide formation, as occurs in phagocytes (Chen \& Deen 2001).

The old paradigm stating that NO is a mere "unspecific" cytostatic mediator of defence has been challenged by the recent discovery that NO has a large variety of effects on the biology of leukocytes. These effects can be direct or indirect and can influence several physiological processes, ranging from DNA transcription and replication to protein synthesis and secretion (Marnett et al. 2003). Under physiological conditions, NO mediates homeostatic anti-inflammatory reactions, such as inhibition of neutrophil adhesion (Dal Secco et al. 2006), cyclooxygenase activity (Gilroy 2005), cytokine production (Livonesi et al. 2009), osteoclast bone resorption (Fukada et al. 2008), among others, in order to prevent autoimmunity. 
The broad spectrum of effects performed by NO can be exerted through two main mechanisms: the activation of guanylate cyclase (which can be soluble in the cytosol or coupled to the cell membrane) (Poulos 2006) or through its interaction with the major cellular source of superoxide anion, the $\mathrm{NO} /$ Cytochrome $\mathrm{C}$ oxidase, which is found in mitochondria.

The guanylate cyclase-dependent effects of NO mainly affect the vascular tonus thereby affecting the inflammatory reaction. Other effects pertaining to mitochondrial functions involve the respiratory burst (Ghafourifar \& Cadenas 2005). Mitochondria can produce NO through its own $\mathrm{Ca}^{2+}$-sensitive synthase (mitochondrial, mtNOS). This enzyme regulates mitochondrial oxygen consumption and transmembrane potential via a reversible reaction with cytochrome $\mathrm{C}$ oxidase. The intramitochondrial reaction of $\mathrm{NO}$ with superoxide anion yields peroxynitrite, which irreversibly modifies susceptible targets within the mitochondria, inducing oxidative and/or nitrative stress.

In addition to their primary role in the production of energy (ATP), mitochondria generate reactive oxygen species (ROS) that can directly or indirectly affect the NO response (Poderoso 2009). Since NO and ONOO- can inhibit cellular respiration at the level of cytochrome $\mathrm{C}$ oxidase and complexes I-III, respectively, it has been suggested that mitochondrial function can influence the balance between apoptosis and necrosis induced by NO (Lizasoain et al. 1996). In addition, NO can stimulate the biogenesis of new mitochondria in a guanosine 3', 5'-monophosphate (cGMP)-dependent manner (Nisoli et al. 2003).

These findings are of particular relevance for $T$. cruzi infection, since it has been described that $T$. cruzi causes an energetic impairment in myocardial mitochondria, without altering the organelle ultra structure (Uyemura et al. 1995). Hence, it is possible that T. cruzi can control the central machinery responsible for energetic metabolism in the host in order to access metabolites that are crucial to its proliferation (Schwarcz de Tarlovsky et al. 1995, Baez et al. 2008). This possibility is crucial and warrants further research in order to understand the mechanisms that induce oxidative stress during T. cruzi infection.

Iron-proteins constitute a predominant scavenger mechanism of NO (Angelo et al. 2008, Richardson \& Lok 2008). As iron is mainly provided by the heme group, it constitutes an additional link between the functions of $\mathrm{NO}$ and the respiratory cycle (Chung et al. 2008). Oxygen drives the conversion of nitrosylhemoglobin in the "tense" structure (or partially nitrosylated, deoxy) to S-nitrosohemoglobin in the "relaxed" structure (or ligand-bound, oxy). In the absence of oxygen, nitroxyl anion (NO-) is liberated in a reaction which produces methemoglobin. The yields of both S-nitrosohemoglobin and methemoglobin are dependent on the $\mathrm{NO} / \mathrm{Hb}$ ratio. These recently discovered reactions have provided new insights into the origin of S-nitrosothiols, methemoglobin and its related valence hybrids.

Mechanistic re-examination of the interactions of NO with other heme proteins containing allosteric thiol sites may be warranted (Gow \& Stamler 1998). In addi- tion, it is well established that, in the Haber-Weiss reaction (a reaction that generates hydroxyl radicals $[\cdot \mathrm{OH}]$ from hydrogen peroxide and superoxide $\left[\bullet_{2}^{-}\right]$), iron has a catalytic role, which leads to the propagation of damaging ROS. Thus, NO appears to be involved in cellular defence against iron-mediated ROS generation, mainly by the induction of cellular iron removal (Larrainzar et al. 2008, Trujillo et al. 2008). The role of these mechanisms in the pathogenesis of T. cruzi-induced myocarditis is currently unknown.

\section{NO and the immune response}

As previously stated, one of the most important functions of $\mathrm{NO}$ in the immune system is in antimicrobial defence (De Groote \& Fang 1995, Fang 1997, Nathan \& Shiloh 2000). Reactive oxygen and nitrogen species derived from $\mathrm{NO}$ are essential for protection against various intracellular pathogens including viruses, bacteria, fungi and protozoans. More specifically, NO has been demonstrated to protect against infection from $T$. cruzi (Figs 1,2) and other protozoa as Toxoplasma gondii, Leishmania major, Leishmania donovani, Plasmodium $s p$ and Schistosoma mansoni (Adams et al. 1990, Vespa et al. 1994, Wynn et al. 1994, James 1995, Stenger et al. 1996, Murray \& Nathan 1999, Brunet 2001). Furthermore, the killing activity of NO has also been shown to be effective in host defence against tumour cells (Huerta et al. 2008) and alloantigens (Shi et al. 2008).

NO is perhaps the most important among the group of early mediators produced by cells of the innate immune system. Phagocytes constitute the first line of microbial defence and they function by sensing the presence of different types of infectious agents (Carneiro-Sampaio \& Coutinho 2007) through pattern recognition receptors, including Toll-like receptors (TLRs) and the most recently described NOD- (NLRs) and RIG-like receptors. These receptors recognise multiple microbial patterns; therefore, they are critical for triggering the production of inflammatory mediators and essential for activation of the adaptive immune response (Schnare et al. 2001, Kanneganti et al. 2007, Underhill 2007). In fact, several antigens derived from intracellular parasites can be recognized by innate immune receptors on macrophages, triggering NOS2 activity (Xie et al. 1992, MacMicking et al. 1997).

NOS2 is produced by antigen-presenting cells (APC) during antigen processing and presentation to $\mathrm{T}$ cells and it can modulate various functions of APCs. It can inhibit the expression of major histocompatibility complex class II molecules in activated macrophages and, at high concentrations, may also inhibit IL-12 synthesis, thus contributing to the desensitization of macrophages after exposure to inflammatory stimuli (van der Veen 2001). Indeed, NO induces transcription of IL-12 p40, but not of IL-12 p35, in human macrophages (Salvucci et al. 1998). The IL-12 p40 homodimer is an antagonist for IL-12 and this antagonism might be at least partially responsible for the reduced Th1 reactivity in the presence of NO (Pahan et al. 2001). However, a new report has indicated that the IL-12 p40 homodimer can also induce 
NO production by microglia (Jana et al. 2009), revealing the complex functions of $\mathrm{NO}$ in innate immunity.

Furthermore, NO affects the immune profile of Th1 cells, as mice with a disrupted NOS2 gene exhibit enhanced Th1 activity, which in turn, can affect the Th1/ Th2 balance (Singh et al. 2000). It has been shown that high amounts of NO prevent apoptosis and, given that Th1 cells are more susceptible to apoptosis than Th2 cells, this represents an additional regulatory mechanism of the Th1/Th2 balance (Xiao et al. 2008).

NO can also affect immune responses through its ability to regulate S-nitrosylation of several components of the apoptotic machinery (Okuda et al. 1996, Melino et al. 1997, Johann et al. 2007, Shibata et al. 2007). Apoptosis is an important process in lymphocyte homeostasis and maturation in the thymus, as well as in lymphocyte proliferation in the periphery. Decreased S-nitrosylation of caspase-3 increases its intracellular enzymatic activity. In addition, Fas-mediated activation of caspase-3 is induced not only by cleavage of the zymogen to its active subunits, but also by denitrosylation of its active thiol site. The regulation of apoptosis by NO has an obvious impact on the strength of effector immune responses.

The cytoprotective properties of low/intermediate levels of NO may limit tissue damage during inflammation (Cattell \& Jansen 1995, Okuda et al. 1996, Niedbala et al. 1999, De Gouw et al. 2001). Interestingly, NO significantly increases the proliferation, division and viability of regulatory T cells (Sakaguchi 2004), a lymphocyte subset which has been shown to be involved in acute experimental T. cruzi infection (Mariano et al. 2008). Indeed, regulatory $\mathrm{T}$ cells induced by NO stimulation (NO-Treg) are as efficient as natural Tregs in suppressing the differentiation of different effector lymphocyte subsets (Niedbala et al. 1999, Packard \& Khan 2003). Furthermore, exposure of murine lymphocytes to NO suppresses IL-2 transcription, reducing clonal expansion and indirectly favouring a Th2 response (TaylorRobinson et al. 1994).

Other important feedback mechanisms mediated by NO, which prevent dysregulated immune responses, include downregulation of cell adhesion and migration, which unchecked, would result in serious and overwhelming inflammatory injury (Biffl et al. 1996, Hokari et al. 1998, Staykova et al. 2003, Dal Secco et al. 2006). Of note, inactivation of P-selectin expression by NO, which affects leukocyte adherence, may also preferentially affect Th1 cell migration (van Wely et al. 1998).

Upon stimulation by cytokines or bacterial lipopolysaccharide (LPS), endothelial cells exhibit increased expression of ICAM-1 in vitro, which contributes to the transmigration of all classes of leukocytes, but mainly neutrophils (Biffl et al. 1996). In addition, NOS2 deficiency or inhibition of NOS or sGC by pharmacological inhibitors, leads to enhanced LPS-induced ICAM-1 expression on mesenteric microcirculation (Dal Secco et al. 2006).

The migration of inflammatory cells may also be affected by the chemical modifications of matrix metalloproteinases (MMPs) (Ridnour et al. 2007). Recently,
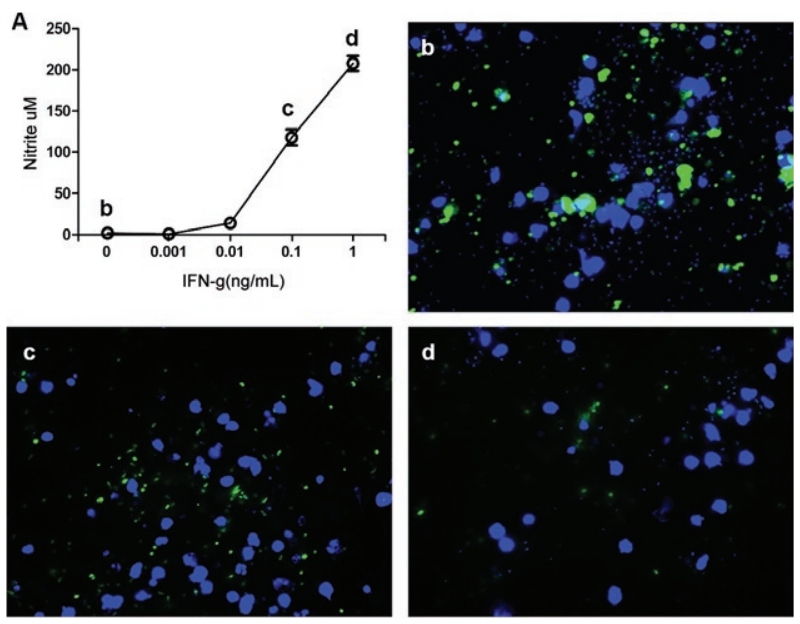

Fig. 1: production of nitric oxide by macrophages correlates with the intracellular killing of Trypanosoma cruzi. Peritoneal murine macrophages were infected with $T$. cruzi and cultured for $48 \mathrm{~h}$ in the presence of recombinant IFN- $\gamma$ as indicated on the $\mathrm{X}$ axis of A. Then, the levels of nitrite were measured in the supernatants by Griess reagent method (A); b, c, d: microphotographs show the parasites (labeled with CFSE before infection) when the cells where not stimulated with IFN-g (b) or with $0.1 \mathrm{ng} / \mathrm{mL}$ (c) or $1 \mathrm{ng} / \mathrm{mL}$ (d) of recombinant IFN- $\gamma$. Note the reduction in the parasite staining as concentration of IFN- $\gamma$ increases in the culture.

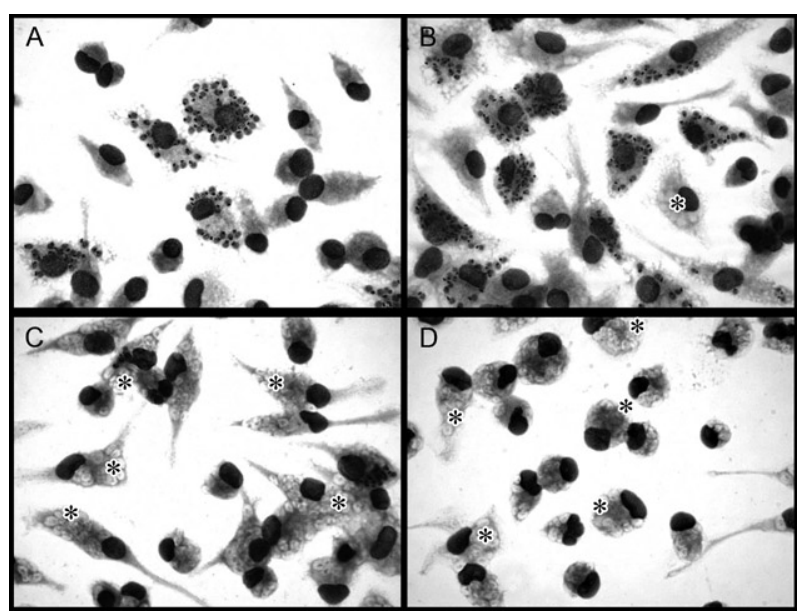

Fig. 2: IFN- $\gamma$ induces macrophage activation and intracellular killing of Trypanosoma cruzi. Peritoneal murine macrophages were cultured for $48 \mathrm{~h}$ in the presence of T. cruzi and medium alone (A, B) or supplemented with $0.1 \mathrm{ng} / \mathrm{mL}$ of recombinant IFN- $\gamma(\mathrm{C}, \mathrm{D})$. Observe in $\mathrm{C}$ and $\mathrm{D}$ the absence of intracellular parasites and, instead of that, empty vacuoles can be noted (asterisks).

it was demonstrated that the activities of MMP-2 and MMP-9 are increased during acute myocarditis in experimental T. cruzi infection and that the inhibition of these enzymes leads to reduced myocarditis and improved survival in mice (Gutierrez et al. 2008). Accordingly, MMPs are activated in inflammatory or ischemic/ reperfusion conditions (Gu et al. 2002). 
NO may also affect lymphocyte migration by altering cell motility. In vitro, NO induces actin polarization in $\mathrm{T}$ cells, inhibiting their trans-endothelial migration in a p70S6 kinase-independent manner (Staykova et al. 2003). Moreover, NO may also inhibit the expression of integrins, such as CD11a/CD18, in neutrophils (Banick et al. 1997, Grisham et al. 1998). Since NOS2 is involved in peroxynitrite-dependent tyrosine nitration (Sato et al. 2000, Yeh et al. 2007), it also regulates chemokine production and affects the inflammatory response mediated by IP-10, MCP-1, MIP-1a and MIP-2, and IL-8 (Mach et al. 1999, Pfeilschifter et al. 2001).

NO also participates in the maintenance of inflammatory diseases (such as arthritis, ulcerative colitis and Crohn's disease) and in the pathogenesis of $T$. cruziinduced myocarditis (Silva et al. 2003, Machado et al. 2008). Indeed, several classic inflammatory symptoms, for example erythema and vascular leakiness, are related to the production of NO and can be reverted by NOS inhibition (Cuzzocrea et al. 2002). In chronic immune responses to intracellular pathogens, $\mathrm{NO}$ is reported to play a regulatory role and may promote parasite persistence. For these reasons, it is suggested that NO is cytostatic rather than cytotoxic for parasites (Klotz et al. 1995).

\section{The dual role of NO during $T$. cruzi infection}

Intracellular protozoans have infected vertebrates since ancient times and are usually able to establish chronic infection. A spontaneous cure is uncommon in these diseases, suggesting that potent mechanisms have been developed by these pathogens in order to evade immune detection or destruction. Among these keystone mechanisms, which attest to their remarkable strength, is the capacity of T. gondii, T. cruzi and Leishmania spp. to invade and replicate within many different cell types (Leiriao et al. 2004, Denkers \& Butcher 2005, Gregory \& Olivier 2005).

Infection with $T$. cruzi in humans can lead to the development of Chagas disease, the clinical features and evolution of which are determined by a combination of parasite factors (i.e. tissue tropism and evasion mechanisms), mode of inoculation (i.e. the mode of contamination or transmission and the size of the inoculum), as well as by host-derived factors (i.e. exacerbated immune response) (Coura 2007).

During T. cruzi infection, NO can directly or indirectly modulate the effector leukocyte machinery through diverse mechanisms. This process involves microbicidal effects derived from toxic-free radicals (peroxinitrite and superoxide) generated after NO production, as well as regulation/enhancement of the inflammatory response induced during this type of infection, a dual role in the immunity that is usually observed for NO. This well-known immune duality is usually dependent on concentration and, once dysregulated, may lead to host cell toxicity, autoimmunity or parasite persistence due to immune evasion, all of which can lead to pathology (FR Gutierrez et al. 2009, unpublished observations).

NO is involved in the control of $T$. cruzi-induced parasitemia and directly kills the parasite in vitro (Vespa et al. 1994) (Figs 1, 2). NO affects T. cruzi by chemically modifying cysteine-containing proteins and/or by binding to metalloproteins that mediate crucial metabolic processes. Recently, it was reported that NO or NO donors can inhibit the catalytic activity of cruzipain, the major papain-like cysteine proteinase in T. cruzi. Analogous to a similar protein in Plasmodium, this dose-dependent effect was attributed to S-nitrosylation of Cys25, a catalytic residue present in the active site of cruzipain (Venturini et al. 2000).

The strength of NO toxicity is dependent on the sensitivity of the parasite, which differs among parasite strains and according to the physiological microenvironment. NO has been demonstrated to be the principal effector molecule involved in macrophage-mediated killing of T. cruzi amastigotes (Nathan \& Shiloh 2000, Colasanti et al. 2002, Silva et al. 2003). Contradictory evidence suggests that susceptible mouse strains display increased macrophage activation after contact with the parasite, which may be due to the fact that, in these animals, infection with $T$. cruzi induces an overwhelming production of both $\mathrm{NO}$ and $\bullet \mathrm{O}_{2}^{-}$(Russo et al. 1989, Cardoni et al. 1990, Arantes et al. 2004).

An additional mechanism by which NO can affect the metabolism of $T$. cruzi is through the reduction of available growth factors. For example, iron is an important growth factor for T. cruzi (Ciccarelli et al. 2007). NO induces nitrosilation of the heme group from haemoglobin, haematin or haemin, the main sources of iron. The main target of oxidative stress during T. cruzi infection is the erythrocyte, as it is the major principle site of the antioxidant chemical machinery. The nature and extent of oxidative injury depends on three factors: (i) the induction of NOS2 and, thus production of NO in response to infection (Alvarez et al. 2004); (ii) the oxidative stress generated outside of the erythrocyte, particularly phagocyte-derived $\cdot \mathrm{O}_{2}^{-}$and (iii) the rate of reaction between $\mathrm{NO}$ and either haemoglobin or $\boldsymbol{}_{2}{ }_{2}^{-}$. The imbalanced counteraction of the oxidative response leads to haematological disorders (i.e., anaemia), which are observed in the acute phase of T. cruzi infection (Malvezi et al. 2004).

Oxidative stress is also observed in myocarditis during experimental T. cruzi infection. As myocarditis progresses, a substantial decline in cardiac mtDNA content (54-60\%) and mitochondria-encoded transcripts (50$65 \%$ indicate that alterations in mtDNA contribute to the quantitative deficiencies in respiratory chain activity of infected individuals (Vyatkina et al. 2004). In fact, during chagasic cardiomyopathy, mitochondrial dysfunction occurs as a consequence of intense oxidative stress (Wen et al. 2006) and is evidenced by deficiencies in respiratory chain complexes (CI-CV) (Garg 2005).

As previously suggested, the accuracy of initial pathogen recognition by the immune system is crucial for the production of NO in order to mount an appropriate immune response. TLRs can sense the presence of T. cruzi (Campos \& Gazzinelli 2004), however, because it is an intracellular protozoan, T. cruzi has an extremely complex antigenic repertoire (Buscaglia et al. 2006). This 
makes it difficult to determine the exact mechanism by which the large diversity of cell-surface molecules on $T$. cruzi are recognised by the innate immune system (Tarleton 2007). Although other molecules may be involved, it is known that innate recognition of glycophosphatidylinositol-anchored mucin-like glycoproteins from $T$. cruzi are potent inducers of NO biosynthesis by IFN- $\gamma$ activated macrophages (Camargo et al. 1997).

Early after infection, IL-12 is required for the induction and maintenance of IFN- $\gamma$ production by innate and adaptive immune cells (Silva et al. 1998). IFN- $\gamma$ production by Th1 effector cells has consistently been implicated in the pathogenesis of Chagas disease and is an important factor for maintaining T. cruzi-mediated pathology. During acute experimental T. cruzi infection in mice, the parasite induces a profound suppression of the lymphoproliferative response to mitogens and $T$. cruzi antigens. This process is largely mediated by increased NO synthesis and decreased IL-2 production (Abrahamsohn \& Coffman 1995). Our group demonstrated that $\mathrm{NO}$ induces apoptosis of cells from BALB/c mice acutely infected by T. cruzi. Splenocytes from infected mice displayed reduced viability and elevated levels of spontaneous apoptosis after $48 \mathrm{~h}$ in culture. Inhibition of NO production, by the addition of the L-arginine analogue NG-monomethyl-L-arginine or the addition of monoclonal antibodies (mAbs) against IFN- $\gamma$ or TNF- $\alpha$ partially restored viability and decreased apoptosis of splenocytes from infected mice (Martins et al. 1998). In addition, the production of IL-17 has recently been implicated in mediating regulatory responses against $T$. cruzi (Monteiro et al. 2007). Of note, IL-17 markedly augments NOS2 mRNA and subsequent NO production. Additionally, T. cruzi infection induces the expression of chemokines (MIG, IP-10, RANTES, MIP) and adhesion molecules at sites of $\mathrm{CD}^{+}$and $\mathrm{CD} 8^{+} \mathrm{T}$ cell infiltration (Teixeira et al. 2002). Cytokines and NO can modulate the production of chemokines and adhesion molecules in vivo and in vitro, influencing the course of infection (Savino et al. 2007, Machado et al. 2008). Chemokine receptors are also involved in cellular activation during parasitic infections and this G-protein-coupled signalling pathway is implicated in NO production as well (Benevides et al. 2008).

One mechanism by which the innate immune response can affect the activation of $\mathrm{T}$ cells is through the macrophage-mediated reduction of available L-arginine in the microenvironment. The levels of this metabolite depend on the cytokine milieu. For example, macrophages stimulated with IL-4 and IL-13 (but not IFN- $\gamma$ ) up-regulate arginase I and the L-arginine receptor CAT$2 \mathrm{~B}$, thus inducing a rapid reduction in the concentrations of L-arginine; this, in turn, down-modulates the expression of $\mathrm{CD} 3 \varepsilon$ in $\mathrm{T}$ lymphocytes reducing their activation (Rodriguez et al. 2003). Arginine is also required for the synthesis of NO, thus this can constitute a feedback mechanism to regulate the immune system. Recently, recognition of intracellular pathogens by TLRs has been implicated in the downregulation of NO production, through increased arginase I activity, in a STAT6- independent manner, which favours parasite growth and survival (El Kasmi et al. 2008).

As one of the most successful parasitic protozoans, $T$. cruzi has evolved active strategies to evade host defences (Eckmann et al. 2000). Interestingly, epimastigote forms of T. cruzi synthesise their own NO through a partially characterized NOS enzyme which displays regulatory and immunochemical properties resembling those of endogenous NOS1 (Pereira et al. 1999, Goldstein et al. 2000, Piacenza et al. 2001).

Furthermore, T. cruzi can also exploit the removal of apoptotic cells by professional phagocytes, which is an important mechanism by which some pathogen-induced cell alterations are ultimately detected and which is involved in the recycling of cellular constituents. Uptake of apoptotic cells does not induce an inflammatory response. Accordingly, macrophages upregulate arginase II after phagocytosis of apoptotic cells, which regulates NO production by NOS2 (Freire-de-Lima et al. 2000, Johann et al. 2007). Additionally, L-arginine, the substrate for NO production, can inhibit the programmed cell death of epimastigotes, either by NOS2-dependent production or by the activity of arginine decarboxylase, which produces polyamines that support parasite proliferation (Paveto et al. 1995).

\section{Implications of NO in therapeutic treatment against Chagas disease}

The current pharmacological agents available to treat Chagas disease include benznidazole (Rochagan and Rodanil; Roche, Brazil) and nifurtimox (Lampit; Bayer, Germany). These drugs are relatively effective in the acute and sub-chronic stages of Chagas disease (Russomando et al. 1998, Sosa Estani et al. 1998, Cançado 2002, Altclas et al. 2005). However, both drugs have significant side effects, including anorexia, vomiting, peripheral polyneuropathy and allergic dermopathy (Rassi et al. 1999). Moreover, several parasite strains are resistant to these treatments, even during the acute phase of the disease (Filardi \& Brener 1987, Galvao et al. 1993, Urbina 1999). The rate of cure observed in patients with these drugs is $50-70 \%$ during the acute phase and $0-20 \%$ during the chronic phase (Guedes et al. 2006). This situation is severely aggravated by the absence of a diagnostic standard, which makes the parameters for a cure, in order to evaluate the outcome of trypanocidal therapies, debatable. Thus, there is an imperative requirement for the development of novel, safe therapeutic agents to treat Chagas disease.

As stated before, parasite elimination largely depends on the production of pro-inflammatory cytokines, such as IFN- $\gamma$, TNF- $\alpha$ and IL-12, as they act in concert to activate macrophages to kill the intracellular parasite through the production of $\mathrm{NO}$ and its derived nitrogen and oxygen radicals (Aliberti et al. 1999, 2001, Machado et al. 2000). Studies using experimental models of acute T. cruzi infection have demonstrated that the anti-parasitic activity of benznidazole involves the participation of these cytokines (Michailowsky et al. 1998, Molina et al. 2000), as well as covalent modifications of macromol- 
ecules by nitroreducer intermediates (reductive stress). Conversely, nifurtimox acts by reducing the nitro group to unstable nitro anion radicals, which, in turn, react to produce highly toxic reduced oxygen metabolites (superoxide anion and hydrogen peroxide) (Docampo 1990).

NO donor compounds have low toxicity in vitro and in vivo and are stable in aqueous media in the presence of oxygen and $\mathrm{NO}$ released by reducing agents that are present in the host inflammatory microenvironment (Bogdan 2001, Silva et al. 2007). These donor compounds have recently emerged as an interesting and important alternative treatment to experimental T. cruzi infection (Silva et al. 2007). We recently reported that a series of ruthenium nitrosyls, trans- $\left[\mathrm{Ru}^{\mathrm{II}}\left(\mathrm{NO}^{+}\right)\left(\mathrm{NH}_{3}\right)_{4} \mathrm{~L}\right]$ $\mathrm{X}_{3}$, L: imidazole " $\{$ imidazole in complex with nitrogen [imN] or imidazole in complex with carbon [imC], pyridine [py], L-histidine [L-hist], sulphite $\left[\mathrm{SO}_{3}^{2-}\right.$, pyrazine [pz], nicotinamide [nic], 4-picoline [4-pic], triethylphosphite $\left[\left(\mathrm{P}(\mathrm{OEt})_{3}\right)\right]$, isonicotinamide [isn], isonicotinic acid [ina], $\mathrm{X}=\mathrm{BF}_{4}^{-}, \mathrm{Cl}^{-}$or $\left.\mathrm{PF}_{6}^{-}\right\}$and $\left[\mathrm{Ru}^{\mathrm{II}}\left(\mathrm{NO}^{+}\right)(\right.$Hedta $\left.)\right]$ display trypanocidal activity against the $\mathrm{Y}$ strain of T. cruzi. Such compounds were efficient in reducing parasitemia, cardiac inflammation and also allowed increased survival of infected mice (Silva et al. 2007). We also showed that the new and more potent NO donor, trans $-\left\{\mathrm{RuCl}\left[(15) \mathrm{aneN}_{4}\right] \mathrm{NO}\right\}^{2+}$ complex $\left[(15) \mathrm{aneN}_{4}=\right.$ 1,4,8,12-tetraazacyclopentadecane, a macrocyclic quadridentate amine ligand] induced parasitological cure in a therapeutic schedule that involved a 20-day treatment of mice infected with the Y strain of T. cruzi. We evaluated the parasitological cure of mice treated with trans$\left\{\mathrm{RuCl}\left[(15) \mathrm{aneN}_{4}\right] \mathrm{NO}\right\}^{2+}$ and compared it to treatment with benznidazole or treatment with both drugs. Benznidazole or trans- $\left\{\mathrm{RuCl}\left[(15) \mathrm{aneN}_{4}\right] \mathrm{NO}^{2+}\right.$ administrated alone resulted in a $40 \%$ and $20 \%$ parasitological cure, respectively. However, when administered together, $80 \%$ of the treated animals were considered cured. These findings were associated with reduced or absent cardiac damage during the acute phase of $T$. cruzi infection (PMM Guedes et al., unpublished observations).

These studies provide evidence that NO donors help to improve the efficacy of current trypanocidal drugs, reducing the time of treatment and preventing adverse reactions. Hence, administration of NO donors and other drugs in conjunction can constitute a promissory therapeutic avenue that could be explored as a new alternative for the treatment of Chagas disease.

In conclusion, NO is essential for host survival during acute experimental T. cruzi infection. Its production is rapidly triggered in cells of the innate immune system, after the parasite is detected, and later by adaptive immune cells. A delicate, yet not completely understood, interplay exists between the components of the immune response and the concentration of NO.

Vast scientific evidence shows that NO can exert its effects on the immune response either directly or through the activity of its derivatives (mainly oxygen and nitrogen reactive species), which are able to induce structural modifications in cytokines and chemokines, thus altering their biological activities. In the same manner, NO can affect the biology of $T$. cruzi by direct toxicity, by affecting essential metabolites, or by enhancing the immune response against the parasite.

Nonetheless, this broad spectrum of activity of NO can also be responsible for extensive damage to the tissues of infected hosts and for manifestation of the disease. These data have led investigators to propose $\mathrm{NO}$ as a crucial target for the immunotherapy of this infectious disease. However, additional studies are required to further understand the multiple roles of $\mathrm{NO}$ and to establish the risks and benefits of such therapeutic approaches during parasitic infection in patients.

\section{REFERENCES}

Abrahamsohn IA, Coffman RL 1995. Cytokine and nitric oxide regulation of the immunosuppression in Trypanosoma cruzi infection. J Immunol 155: 3955-3963.

Adams LB, Hibbs JB Jr, Taintor RR, Krahenbuhl JL 1990. Microbiostatic effect of murine-activated macrophages for Toxoplasma gondii. Role for synthesis of inorganic nitrogen oxides from Larginine. J Immunol 144: 2725-2729.

Aliberti JC, Machado FS, Souto JT, Campanelli AP, Teixeira MM, Gazzinelli RT, Silva JS 1999. beta-Chemokines enhance parasite uptake and promote nitric oxide-dependent microbiostatic activity in murine inflammatory macrophages infected with Trypanosoma cruzi. Infect Immun 67: 4819-4826.

Aliberti JC, Souto JT, Marino AP, Lannes-Vieira J, Teixeira MM, Farber J, Gazzinelli RT, Silva JS 2001. Modulation of chemokine production and inflammatory responses in interferon-gammaand tumor necrosis factor-R1-deficient mice during Trypanosoma cruzi infection. Am J Pathol 158: 1433-1440.

Altclas J, Sinagra A, Dictar M, Luna C, Veron MT, De Rissio AM, Garcia MM, Salgueira C, Riarte A 2005. Chagas disease in bone marrow transplantation: an approach to preemptive therapy. Bone Marrow Transplant 36: 123-129.

Alvarez MN, Piacenza L, Irigoin F, Peluffo G, Radi R 2004. Macrophage-derived peroxynitrite diffusion and toxicity to Trypanosoma cruzi. Arch Biochem Biophys 432: 222-232.

Angelo M, Hausladen A, Singel DJ, Stamler JS 2008. Interactions of NO with hemoglobin: from microbes to man. Methods Enzymol 436: 131-168.

Arantes RM, Marche HH, Bahia MT, Cunha FQ, Rossi MA, Silva JS 2004. Interferon-gamma-induced nitric oxide causes intrinsic intestinal denervation in Trypanosoma cruzi-infected mice. Am J Pathol 164: 1361-1368.

Baez AL, Lo Presti MS, Rivarola HW, Pons P, Fretes R, Paglini-Oliva P 2008. Trypanosoma cruzi: cardiac mitochondrial alterations produced by different strains in the acute phase of the infection. Exp Parasitol 120: 397-402.

Banick PD, Chen Q, Xu YA, Thom SR 1997. Nitric oxide inhibits neutrophil beta 2 integrin function by inhibiting membrane-associated cyclic GMP synthesis. J Cell Physiol 172: 12-24.

Benevides L, Milanezi CM, Yamauchi LM, Benjamim CF, Silva JS, Silva NM 2008. CCR2 receptor is essential to activate microbicidal mechanisms to control Toxoplasma gondii infection in the central nervous system. Am J Pathol 173: 741-751.

Biffl WL, Moore EE, Moore FA, Barnett C 1996. Nitric oxide reduces endothelial expression of intercellular adhesion molecule (ICAM)-1. J Surg Res 63: 328-332.

Bogdan C 2001. Nitric oxide and the immune response. Nat Immunol 2: $907-916$. 
Brunet LR 2001. Nitric oxide in parasitic infections. Int Immunopharmacol 1: 1457-1467.

Buscaglia CA, Campo VA, Frasch AC, Di Noia JM 2006. Trypanosoma cruzi surface mucins: host-dependent coat diversity. Nat Rev Microbiol 4: 229-236.

Camargo MM, Almeida IC, Pereira ME, Ferguson MA, Travassos LR, Gazzinelli RT 1997. Glycosylphosphatidylinositol-anchored mucin-like glycoproteins isolated from Trypanosoma cruzi trypomastigotes initiate the synthesis of proinflammatory cytokines by macrophages. J Immunol 158: 5890-5901.

Campos MA, Gazzinelli RT 2004. Trypanosoma cruzi and its components as exogenous mediators of inflammation recognized through Toll-like receptors. Mediators Inflamm 13: 139-143.

Cançado JR 2002. Long term evaluation of etiological treatment of Chagas disease with benznidazole. Rev Inst Med Trop São Paulo 44: 29-37.

Cardoni RL, Rottenberg ME, Segura EL 1990. Increased production of reactive oxygen species by cells from mice acutely infected with Trypanosoma cruzi. Cell Immunol 128: 11-21.

Carneiro-Sampaio M, Coutinho A 2007. Immunity to microbes: lessons from primary immunodeficiencies. Infect Immun 75: 1545-1555.

Cattell V, Jansen A 1995. Inducible nitric oxide synthase in inflammation. Histochem J 27: 777-784.

Chen B, Deen WM 2001. Analysis of the effects of cell spacing and liquid depth on nitric oxide and its oxidation products in cell cultures. Chem Res Toxicol 14: 135-147.

Chung HT, Choi BM, Kwon YG, Kim YM 2008. Interactive relations between nitric oxide (NO) and carbon monoxide (CO): heme oxygenase-1/CO pathway is a key modulator in NO-mediated antiapoptosis and anti-inflammation. Methods Enzymol 441: 329-338.

Ciccarelli A, Araujo L, Batlle A, Lombardo E 2007. Effect of haemin on growth, protein content and the antioxidant defence system in Trypanosoma cruzi. Parasitology 134: 959-965.

Colasanti M, Gradoni L, Mattu M, Persichini T, Salvati L, Venturini G, Ascenzi P 2002. Molecular bases for the anti-parasitic effect of NO (review). Int J Mol Med 9: 131-134.

Coura JR 2007. Chagas disease: what is known and what is needed: a background article. Mem Inst Oswaldo Cruz 102 (Suppl. I): 113-122.

Cuzzocrea S, Chatterjee PK, Mazzon E, McDonald MC, Dugo L, Di Paola R, Serraino I, Britti D, Caputi AP, Thiemermann C 2002. Beneficial effects of GW274150, a novel, potent and selective inhibitor of iNOS activity, in a rodent model of collagen-induced arthritis. Eur J Pharmacol 453: 119-129.

Dal Secco D, Moreira AP, Freitas A, Silva JS, Rossi MA, Ferreira SH, Cunha FQ 2006. Nitric oxide inhibits neutrophil migration by a mechanism dependent on ICAM-1: role of soluble guanylate cyclase. Nitric Oxide 15: 77-86.

De Gouw HW, Marshall-Partridge SJ, Van Der Veen H, Van Den Aardweg JG, Hiemstra PS, Sterk PJ 2001. Role of nitric oxide in the airway response to exercise in healthy and asthmatic subjects. J Appl Physiol 90: 586-592.

De Groote MA, Fang FC 1995. NO inhibitions: antimicrobial properties of nitric oxide. Clin Infect Dis 21 (Suppl. 2): S162-165.

Denkers EY, Butcher BA 2005. Sabotage and exploitation in macrophages parasitized by intracellular protozoans. Trends Parasitol 21: 35-41.

Docampo R 1990. Sensitivity of parasites to free radical damage by antiparasitic drugs. Chem Biol Interact 73: 1-27.
Eckmann L, Laurent F, Langford TD, Hetsko ML, Smith JR, Kagnoff MF, Gillin FD 2000. Nitric oxide production by human intestinal epithelial cells and competition for arginine as potential determinants of host defense against the lumen-dwelling pathogen Giardia lamblia. J Immunol 164: 1478-1487.

El Kasmi KC, Qualls JE, Pesce JT, Smith AM, Thompson RW, Henao-Tamayo M, Basaraba RJ, Konig T, Schleicher U, Koo MS, Kaplan G, Fitzgerald KA, Tuomanen EI, Orme IM, Kanneganti TD, Bogdan C, Wynn TA, Murray PJ 2008. Toll-like receptorinduced arginase 1 in macrophages thwarts effective immunity against intracellular pathogens. Nat Immunol 9: 1399-1406.

Fang FC 1997. Perspectives series: host/pathogen interactions. Mechanisms of nitric oxide-related antimicrobial activity: J Clin Invest 99: 2818-2825.

Filardi LS, Brener Z 1987: Susceptibility and natural resistance of Trypanosoma cruzi strains to drugs used clinically in Chagas disease. Trans R Soc Trop Med Hyg 81: 755-759.

Freire-de-Lima CG, Nascimento DO, Soares MB, Bozza PT, CastroFaria-Neto HC, de Mello FG, DosReis GA, Lopes MF 2000. Uptake of apoptotic cells drives the growth of a pathogenic trypanosome in macrophages. Nature 403: 199-203.

Fukada SY, Silva TA, Saconato IF, Garlet GP, Avila-Campos MJ, Silva JS, Cunha FQ 2008. iNOS-derived nitric oxide modulates infection-stimulated bone loss. J Dent Res 87: 1155-1159.

Furchgott RF, Zawadzki JV 1980. The obligatory role of endothelial cells in the relaxation of arterial smooth muscle by acetylcholine. Nature 288: 373-376.

Galvao LM, Nunes RM, Cançado JR, Brener Z, Krettli AU 1993. Lytic antibody titre as a means of assessing cure after treatment of Chagas disease: a 10 years follow-up study. Trans $R$ Soc Trop Med Hyg 87: 220-223.

Garg N 2005. Mitochondrial disorders in chagasic cardiomyopathy. Front Biosci 10: 1341-1354.

Ghafourifar P, Cadenas E 2005. Mitochondrial nitric oxide synthase. Trends Pharmacol Sci 26: 190-195.

Gilroy DW 2005. New insights into the anti-inflammatory actions of aspirin-induction of nitric oxide through the generation of epilipoxins. Mem Inst Oswaldo Cruz 100 (Suppl. I): 49-54.

Goldstein J, Paveto C, Lopez-Costa JJ, Pereira C, Alonso G, Torres HN, Flawia MM 2000. Immuno and cytochemical localization of Trypanosoma cruzi nitric oxide synthase. Biocell 24: 217-222.

Gow AJ, Stamler JS 1998. Reactions between nitric oxide and haemoglobin under physiological conditions. Nature 391: 169-173.

Gregory DJ, Olivier M 2005. Subversion of host cell signalling by the protozoan parasite Leishmania. Parasitology 130 (Suppl.): S27-35.

Grisham MB, Granger DN, Lefer DJ 1998. Modulation of leukocyteendothelial interactions by reactive metabolites of oxygen and nitrogen: relevance to ischemic heart disease. Free Radic Biol Med 25: 404-433.

Gu Z, Kaul M, Yan B, Kridel SJ, Cui J, Strongin A, Smith JW, Liddington RC, Lipton SA 2002. S-nitrosylation of matrix metalloproteinases: signaling pathway to neuronal cell death. Science 297: 1186-1190.

Guedes PMM, Fietto JLR, Lana M, Bahia MT 2006. Advances in Chagas disease chemotherapy. Anti-Infect Agents Med Chem 5: 11.

Gutierrez FR, Lalu MM, Mariano FS, Milanezi CM, Cena J, Gerlach RF, Santos JE, Torres-Duenas D, Cunha FQ, Schulz R, Silva JS 2008. Increased activities of cardiac matrix metalloproteinases matrix metalloproteinase (MMP)-2 and MMP-9 are associated 
with mortality during the acute phase of experimental Trypanosoma cruzi infection. J Infect Dis 197: 1468-1476.

Hokari R, Miura S, Fujimori H, Tsuzuki Y, Shigematsu T, Higuchi H, Kimura H, Kurose I, Serizawa H, Suematsu M, Yagita H, Granger DN, Ishii H 1998. Nitric oxide modulates T-lymphocyte migration in Peyer's patches and villous submucosa of rat small intestine. Gastroenterology 115: 618-627.

Huerta S, Chilka S, Bonavida B 2008. Nitric oxide donors: novel cancer therapeutics (review). Int J Oncol 33: 909-927.

James SL 1995. Role of nitric oxide in parasitic infections. Microbiol Rev 59: 533-547.

Jana M, Dasgupta S, Pal U, Pahan K 2009. IL-12 p40 homodimer, the so-called biologically inactive molecule, induces nitric oxide synthase in microglia via IL-12Rbeta1. Glia, in press.

Johann AM, Barra V, Kuhn AM, Weigert A, von Knethen A, Brune B 2007. Apoptotic cells induce arginase II in macrophages, thereby attenuating NO production. Faseb J 21: 2704-2712.

Kanneganti TD, Lamkanfi M, Nunez G 2007. Intracellular NOD-like receptors in host defense and disease. Immunity 27: 549-559.

Klotz FW, Scheller LF, Seguin MC, Kumar N, Marletta MA, Green SJ, Azad AF 1995. Co-localization of inducible-nitric oxide synthase and Plasmodium berghei in hepatocytes from rats immunized with irradiated sporozoites. J Immunol 154: 3391-3395.

Larrainzar E, Urarte E, Auzmendi I, Ariz I, Arrese-Igor C, Gonzalez EM, Moran JF 2008. Use of recombinant iron-superoxide dismutase as a marker of nitrative stress. Methods Enzymol 437: 605-618.

Leiriao P, Rodrigues CD, Albuquerque SS, Mota MM 2004. Survival of protozoan intracellular parasites in host cells. EMBO Rep 5: 1142-1147.

Livonesi MC, Rossi MA, de Souto JT, Campanelli AP, de Sousa RL, Maffei CM, Ferreira BR, Martinez R, da Silva JS 2009. Inducible nitric oxide synthase-deficient mice show exacerbated inflammatory process and high production of both Th1 and Th2 cytokines during paracoccidioidomycosis. Microbes Infect 11: 123-132.

Lizasoain I, Moro MA, Knowles RG, Darley-Usmar V, Moncada S 1996. Nitric oxide and peroxynitrite exert distinct effects on mitochondrial respiration which are differentially blocked by glutathione or glucose. Biochem J 314: 877-880.

Mach F, Sauty A, Iarossi AS, Sukhova GK, Neote K, Libby P, Luster AD 1999. Differential expression of three T lymphocyte-activating CXC chemokines by human atheroma-associated cells. J Clin Invest 104: 1041-1050.

Machado FS, Martins GA, Aliberti JC, Mestriner FL, Cunha FQ, Silva JS 2000. Trypanosoma cruzi-infected cardiomyocytes produce chemokines and cytokines that trigger potent nitric oxidedependent trypanocidal activity. Circulation 102: 3003-3008.

Machado FS, Souto JT, Rossi MA, Esper L, Tanowitz HB, Aliberti J, Silva JS 2008. Nitric oxide synthase-2 modulates chemokine production by Trypanosoma cruzi-infected cardiac myocytes. Microbes Infect 10: 1558-1566.

MacMicking J, Xie QW, Nathan C 1997. Nitric oxide and macrophage function. Annu Rev Immunol 15: 323-350.

Malvezi AD, Cecchini R, de Souza F, Tadokoro CE, Rizzo LV, PingeFilho P 2004. Involvement of nitric oxide (NO) and TNF-alpha in the oxidative stress associated with anemia in experimental Trypanosoma cruzi infection. FEMS Immunol Med Microbiol 41: 69-77.

Mariano FS, Gutierrez FR, Pavanelli WR, Milanezi CM, Cavassani KA, Moreira AP, Ferreira BR, Cunha FQ, Cardoso CR, Silva JS
2008. The involvement of $\mathrm{CD} 4^{+} \mathrm{CD} 25^{+} \mathrm{T}$ cells in the acute phase of Trypanosoma cruzi infection. Microbes Infect 10: 825-833.

Marnett LJ, Riggins JN, West JD 2003. Endogenous generation of reactive oxidants and electrophiles and their reactions with DNA and protein. J Clin Invest 111: 583-593.

Martins GA, Cardoso MA, Aliberti JC, Silva JS 1998. Nitric oxideinduced apoptotic cell death in the acute phase of Trypanosoma cruzi infection in mice. Immunol Lett 63: 113-120.

Melino G, Bernassola F, Knight RA, Corasaniti MT, Nistico G, Finazzi-Agro A 1997. S-nitrosylation regulates apoptosis. Nature 388: 432-433.

Michailowsky V, Murta SM, Carvalho-Oliveira L, Pereira ME, Ferreira LR, Brener Z, Romanha AJ, Gazzinelli RT 1998. Interleukin-12 enhances in vivo parasiticidal effect of benznidazole during acute experimental infection with a naturally drug-resistant strain of Trypanosoma cruzi. Antimicrob Agents Chemother 42: 2549-2556.

Molina J, Martins-Filho O, Brener Z, Romanha AJ, Loebenberg D, Urbina JA 2000. Activities of the triazole derivative SCH 56592 (posaconazole) against drug-resistant strains of the protozoan parasite Trypanosoma (Schizotrypanum) cruzi in immunocompetent and immunosuppressed murine hosts. Antimicrob Agents Chemother 44: 150-155.

Monteiro AC, Schmitz V, Morrot A, de Arruda LB, Nagajyothi F, Granato A, Pesquero JB, Muller-Esterl W, Tanowitz HB, Scharfstein J 2007. Bradykinin B2 receptors of dendritic cells, acting as sensors of kinins proteolytically released by Trypanosoma cruzi, are critical for the development of protective type-1 responses. PLoS Pathog 3: e185.

Murad F 1986. Cyclic guanosine monophosphate as a mediator of vasodilation. J Clin Invest 78: 1-5.

Murray HW, Nathan CF 1999. Macrophage microbicidal mechanisms in vivo: reactive nitrogen versus oxygen intermediates in the killing of intracellular visceral Leishmania donovani. J Exp Med 189: 741-746.

Nathan C, Shiloh MU 2000. Reactive oxygen and nitrogen intermediates in the relationship between mammalian hosts and microbial pathogens. Proc Natl Acad Sci USA 97: 8841-8848.

Niedbala W, Wei XQ, Piedrafita D, Xu D, Liew FY 1999. Effects of nitric oxide on the induction and differentiation of Th1 cells. Eur J Immunol 29: 2498-2505.

Nisoli E, Clementi E, Paolucci C, Cozzi V, Tonello C, Sciorati C, Bracale R, Valerio A, Francolini M, Moncada S, Carruba MO 2003. Mitochondrial biogenesis in mammals: the role of endogenous nitric oxide. Science 299: 896-899.

Okuda Y, Sakoda S, Shimaoka M, Yanagihara T 1996. Nitric oxide induces apoptosis in mouse splenic T lymphocytes. Immunol Lett 52: $135-138$.

Packard KA, Khan MM 2003. Effects of histamine on Th1/Th2 cytokine balance. Int Immunopharmacol 3: 909-920.

Pahan K, Sheikh FG, Liu X, Hilger S, McKinney M, Petro TM 2001. Induction of nitric-oxide synthase and activation of NF-kappaB by interleukin-12 p40 in microglial cells. $J$ Biol Chem 276: 7899-7905.

Paveto C, Pereira C, Espinosa J, Montagna AE, Farber M, Esteva M, Flawia MM, Torres HN 1995. The nitric oxide transduction pathway in Trypanosoma cruzi. J Biol Chem 270: 16576-16579.

Pereira CA, Alonso GD, Paveto MC, Flawia MM, Torres HN 1999. L-arginine uptake and L-phosphoarginine synthesis in Trypanosoma cruzi. J Eukaryot Microbiol 46: 566-570. 
Pfeilschifter J, Eberhardt W, Beck KF 2001. Regulation of gene expression by nitric oxide. Pflugers Arch 442: 479-486.

Piacenza L, Peluffo G, Radi R 2001. L-arginine-dependent suppression of apoptosis in Trypanosoma cruzi: contribution of the nitric oxide and polyamine pathways. Proc Natl Acad Sci USA 98: 7301-7306.

Poderoso JJ 2009. The formation of peroxynitrite in the applied physiology of mitochondrial nitric oxide. Arch Biochem Biophys 484: 214-220.

Poulos TL 2006. Soluble guanylate cyclase. Curr Opin Struct Biol 16: 736-743.

Rassi A, Amato Neto V, de Siqueira AF, Ferriolli Filho F, Amato VS, Rassi Junior A 1999. Protective effect of benznidazole against parasite reactivation in patients chronically infected with Trypanosoma cruzi and treated with corticoids for associated diseases. Rev Soc Bras Med Trop 32: 475-482.

Ribeiro JM, Hazzard JM, Nussenzveig RH, Champagne DE, Walker FA 1993. Reversible binding of nitric oxide by a salivary heme protein from a bloodsucking insect. Science 260: 539-541.

Richardson DR, Lok HC 2008. The nitric oxide-iron interplay in mammalian cells: transport and storage of dinitrosyl iron complexes. Biochim Biophys Acta 1780: 638-651.

Ridnour LA, Windhausen AN, Isenberg JS, Yeung N, Thomas DD, Vitek MP, Roberts DD, Wink DA 2007. Nitric oxide regulates matrix metalloproteinase- 9 activity by guanylyl-cyclase-dependent and -independent pathways. Proc Natl Acad Sci USA 104: 16898-16903.

Rodriguez PC, Zea AH, DeSalvo J, Culotta KS, Zabaleta J, Quiceno DG, Ochoa JB, Ochoa AC 2003. L-arginine consumption by macrophages modulates the expression of $\mathrm{CD} 3$ zeta chain in $\mathrm{T}$ lymphocytes. J Immunol 171: 1232-1239.

Russo M, Starobinas N, Ribeiro-Dos-Santos R, Minoprio P, Eisen H, Hontebeyrie-Joskowicz M 1989. Susceptible mice present higher macrophage activation than resistant mice during infections with myotropic strains of Trypanosoma cruzi. Parasite Immunol 11: 385-395.

Russomando G, de Tomassone MM, de Guillen I, Acosta N, Vera N, Almiron M, Candia N, Calcena MF, Figueredo A 1998. Treatment of congenital Chagas' disease diagnosed and followed up by the polymerase chain reaction. Am J Trop Med Hyg 59: 487-491.

Sakaguchi S 2004. Naturally arising CD4+ regulatory T cells for immunologic self-tolerance and negative control of immune responses. Annu Rev Immunol 22: 531-562.

Salvucci O, Kolb JP, Dugas B, Dugas N, Chouaib S 1998. The induction of nitric oxide by interleukin-12 and tumor necrosis factoralpha in human natural killer cells: relationship with the regulation of lytic activity. Blood 92: 2093-2102.

Sato E, Simpson KL, Grisham MB, Koyama S, Robbins RA 2000. Reactive nitrogen and oxygen species attenuate interleukin- 8-induced neutrophil chemotactic activity in vitro. J Biol Chem 275: 10826-10830.

Savino W, Villa-Verde DM, Mendes-da-Cruz DA, Silva-Monteiro E, Perez AR, Aoki M del P, Bottasso O, Guinazu N, Silva-Barbosa SD, Gea S 2007. Cytokines and cell adhesion receptors in the regulation of immunity to Trypanosoma cruzi. Cytokine Growth Factor Rev 18: 107-124.

Schnare M, Barton GM, Holt AC, Takeda K, Akira S, Medzhitov R 2001. Toll-like receptors control activation of adaptive immune responses. Nat Immunol 2: 947-950.

Schwarcz de Tarlovsky MN, Rilo MC, Hernandez SM, Bedoya AM, Lammel EM, Isola EL 1995. Spermine action on mitochondrial
$\mathrm{H}(+)$-ATPase activity and proliferation rate of Trypanosoma cruzi. Cell Mol Biol 41: 861-866.

Shi CS, Shi GY, Hsiao SM, Kao YC, Kuo KL, Ma CY, Kuo CH, Chang BI, Chang CF, Lin CH, Wong CH, Wu HL 2008. Lectinlike domain of thrombomodulin binds to its specific ligand Lewis $\mathrm{Y}$ antigen and neutralizes lipopolysaccharide-induced inflammatory response. Blood 112: 3661-3670.

Shibata T, Nagata K, Kobayashi Y 2007. Cutting edge: a critical role of nitrogen oxide in preventing inflammation upon apoptotic cell clearance. J Immunol 179: 3407-3411.

Silva JJ, Osakabe AL, Pavanelli WR, Silva JS, Franco DW 2007. In vitro and in vivo antiproliferative and trypanocidal activities of ruthenium NO donors. Br J Pharmacol 152: 112-121.

Silva JS, Aliberti JC, Martins GA, Souza MA, Souto JT, Padua MA 1998. The role of IL-12 in experimental Trypanosoma cruzi infection. Braz J Med Biol Res 31: 111-115.

Silva JS, Machado FS, Martins GA 2003. The role of nitric oxide in the pathogenesis of Chagas disease. Front Biosci 8: S314-325.

Singh VK, Mehrotra S, Narayan P, Pandey CM, Agarwal SS 2000. Modulation of autoimmune diseases by nitric oxide. Immunol Res 22: 1-19.

Sosa Estani S, Segura EL, Ruiz AM, Velazquez E, Porcel BM, Yampotis C 1998. Efficacy of chemotherapy with benznidazole in children in the indeterminate phase of Chagas' disease. Am $J$ Trop Med Hyg 59: 526-529.

Staykova MA, Berven LA, Cowden WB, Willenborg DO, Crouch MF 2003. Nitric oxide induces polarization of actin in encephalitogenic $\mathrm{T}$ cells and inhibits their in vitro trans-endothelial migration in a p70S6 kinase-independent manner. Faseb $J$ 17: 1337-1339.

Stenger S, Donhauser N, Thuring H, Rollinghoff M, Bogdan C 1996. Reactivation of latent leishmaniasis by inhibition of inducible nitric oxide synthase. J Exp Med 183: 1501-1514.

Tarleton RL 2007. Immune system recognition of Trypanosoma cruzi. Curr Opin Immunol 19: 430-434.

Taylor-Robinson AW, Liew FY, Severn A, Xu D, McSorley SJ, Garside P, Padron J, Phillips RS 1994. Regulation of the immune response by nitric oxide differentially produced by T helper type 1 and T helper type 2 cells. Eur J Immunol 24: 980-984.

Teixeira MM, Gazzinelli RT, Silva JS 2002. Chemokines, inflammation and Trypanosoma cruzi infection. Trends Parasitol 18: 262-265.

Trujillo M, Ferrer-Sueta G, Radi R 2008. Peroxynitrite detoxification and its biologic implications. Antioxid Redox Signal 10: 1607-1620.

Underhill DM 2007. Collaboration between the innate immune receptors dectin-1, TLRs, and Nods. Immunol Rev 219: 75-87.

Urbina JA 1999. Parasitological cure of Chagas disease: is it possible? Is it relevant? Mem Inst Oswaldo Cruz 94 (Suppl. I): 349-355.

Uyemura SA, Albuquerque S, Curti C 1995. Energetics of heart mitochondria during acute phase of Trypanosoma cruzi infection in rats. Int J Biochem Cell Biol 27: 1183-1189.

van der Veen RC 2001. Nitric oxide and T helper cell immunity. Int Immunopharmacol 1: 1491-1500.

van Wely CA, Blanchard AD, Britten CJ 1998. Differential expression of alpha3 fucosyltransferases in Th1 and Th2 cells correlates with their ability to bind P-selectin. Biochem Biophys Res Commun 247: 307-311. 
Venturini G, Salvati L, Muolo M, Colasanti M, Gradoni L, Ascenzi P 2000. Nitric oxide inhibits cruzipain, the major papain-like cysteine proteinase from Trypanosoma cruzi. Biochem Biophys Res Commun 270: 437-441.

Vespa GN, Cunha FQ, Silva JS 1994. Nitric oxide is involved in control of Trypanosoma cruzi-induced parasitemia and directly kills the parasite in vitro. Infect Immun 62: 5177-5182.

Vyatkina G, Bhatia V, Gerstner A, Papaconstantinou J, Garg N 2004. Impaired mitochondrial respiratory chain and bioenergetics during chagasic cardiomyopathy development. Biochim Biophys Acta 1689: 162-173.

Wen JJ, Yachelini PC, Sembaj A, Manzur RE, Garg NJ 2006. Increased oxidative stress is correlated with mitochondrial dysfunction in chagasic patients. Free Radic Biol Med 41: 270-276.

Wynn TA, Oswald IP, Eltoum IA, Caspar P, Lowenstein CJ, Lewis FA, James SL, Sher A 1994. Elevated expression of Th1 cytok- ines and nitric oxide synthase in the lungs of vaccinated mice after challenge infection with Schistosoma mansoni. J Immunol 153: 5200-5209.

Xiao BG, Ma CG, Xu LY, Link H, Lu CZ 2008. IL-12/IFN-gamma/ NO axis plays critical role in development of Th1-mediated experimental autoimmune encephalomyelitis. Mol Immunol 45: 1191-1196.

Xie QW, Cho HJ, Calaycay J, Mumford RA, Swiderek KM, Lee TD, Ding A, Troso T, Nathan C 1992. Cloning and characterization of inducible nitric oxide synthase from mouse macrophages. Science 256: 225-228.

Yeh CL, Hsu CS, Chen SC, Hou YC, Chiu WC, Yeh SL 2007. Effect of arginine on cellular adhesion molecule expression and leukocyte transmigration in endothelial cells stimulated by biological fluid from surgical patients. Shock 28: 39-44. 